The book is divided into five sections (with their associated graphs): general gas data, ammonia data, nitric acid data, hydrogen purification data, and miscellaneous data.

It will suffice to say that in no other publication have we found so adequate and up-to-date a summary of results. One wishes that other branches of physics and chemistry could be treated in a similarly comprehensive manner, and the whole issued as the British answer to "Landolt." It would be large, and doubtless expensive, but imagine its utility! And we need not despair, for we have now got an English Baedeker-blue-and that is only a beginning.

It is not clear from the copy before us to what extent the publication will be available to the general public, or how it may be obtained, or what its cost will be to the would-be purchaser. We trust that there will be no difficulties on tbese scores, for, both for its own worth and as an earnest of many more good things of the' same kind, the present volume deserves a wide circulation.

\section{BIOLOGY AND WAR. ${ }^{1}$}

DROF. RAYMOND PEARL makes in the lecture before us an interesting examination of the biological philosophy of war. The primary implements are not mechanisms, but biological entities - men. The primary problems of war are biological problems-why do men fight, what kinds of men make the best fighters, what conditions conduce to the most effective fighting, and what are the probable consequences of the fight to the winner and the loser? "In general, why men deliberately plan wars is because they are different biologically, in structure, habits, mental outlook, thought, or other ways, and wish to preserve intact their differentiations." The group differences have an emotional context of passion, and the modern physiologists have shown us "why rage is more generally followed by fighting than by judicial arbitration." As to the belief, held with particular tenacity in Germany, that warfare is in line with the process of nature selection which has made on the whole for progressive evolution, it must be.pointed out that "nowhere in nature does natural selection, as indicated by modern careful study of the subject, operate with anything like that mechanistic precision which the German political philosophy postulates; . . . much less does natural selection operate in a rigid and mechanical manner with reference to human affairs;... military results are not, in fact, measured in terms of biological survival." "The plain fact in the matter is that the proudly ruthless philosophy of Treitschke and Bernhardi is not only immorally cruel, but also immortally stupid."

As to the widespread fear that this war will have a serious dysgenic effect by the elimination of so many exceedingly desirable types, Prof.

1 A lecture given before the Washington Academy of Sciences on May 9 , 1918. Journ, Washington Acad. Sci., vol. viii. (1918), No. 1r, pp. 341-6o." NO. $255 \mathrm{I}$, VOL. IO2]
Pearl points out that the racial qualities are continued in the females, that many fighters have left progeny before they fell, that a large proportion of the total male population is not involved in the war, and so on. Nevertheless, it seems to us that Prof. Pearl is very optimistic in concluding that "any putative, deleterious, selective effect" "of the present war "on the races concerned will be insignificantly slight." Most readers of NATURE will, we believe, know personally of several highly distinguished and markedly original men, whose deaths on the field have left the race, whatever statisticians may say, very definitely the poorer. These unique patterns may recur perhaps; for the present they are gone; and we know not how to replace them.

\section{NOTES.}

THE council of the South African Association for the Advancement of Science has resolved to institute a Sir David Gill memorial fund, to accumulate for a number of years until an amount has been raised adequate for some purpose to be decided upon. $\mathrm{Mr}$. R. T. A. Innes, Lnion Observatory, Johannesburg, has consented to act as the secretary and treasurer of the fund, and intending subscribers are invited to communicate with him.

Prof. H. C. H. Carpenter, the president of the Institute of Metals, has been nominated to fill the office for a further year.

Dr. H. S. Hele-Shaw, F.R.S., and Signor Marconi have been elected honorary fellows of the Society of Engineers (Inc.).

Sir John Marshall, Director-General of Archæology in India, has, in consequence of illness, been granted leave of absence, during which his deputy will be $\mathrm{Dr}$. Spooner, Superintendent of Archæology, Eastern Circle.

A Commrtiee on explosives investigations has been selected by the U.S. National Research Council at the request of the American Secretary of War and the Secretary of the Navy. The committee consists of Dr. C. E. Munroe, of the George Washington University (chairman); Mr. L. L. Summers, of the War Industries Board; Lt.-Col. W. C. Spruance, jun., of the Ordnance Department of the Army; and Lt.Commdr. T. S. Wilkinson, of the Ordnance Department of the Navy.

Dr. J. N. Rose, a curator of the division of plants, the U.S. National Museum, has gone on a botanical expedition to Ecuador on behalf of the National Herbarium, the U.S. Department of Agriculture, the New York Botanical Garden, and the Gray Herbarium.

Dr. Olaf Anderson, petrologist at the U.S. Geophysical Laboratory, has resigned his position, having been appointed Government geologist and director of an experimental silicate laboratory at Christiania.

ON September 3 there died in a nursing home in London, only three months after her "Life of Sophia Jex-Blake" had been published, Dr. Margaret Todd, the authoress. Dr. Todd was known to many readers as "Graham Travers," under which nom de plume her five novels were written. Dr. Todd, born in 1859 , was educated at Edinburgh, Glasgow, and Berlin, 